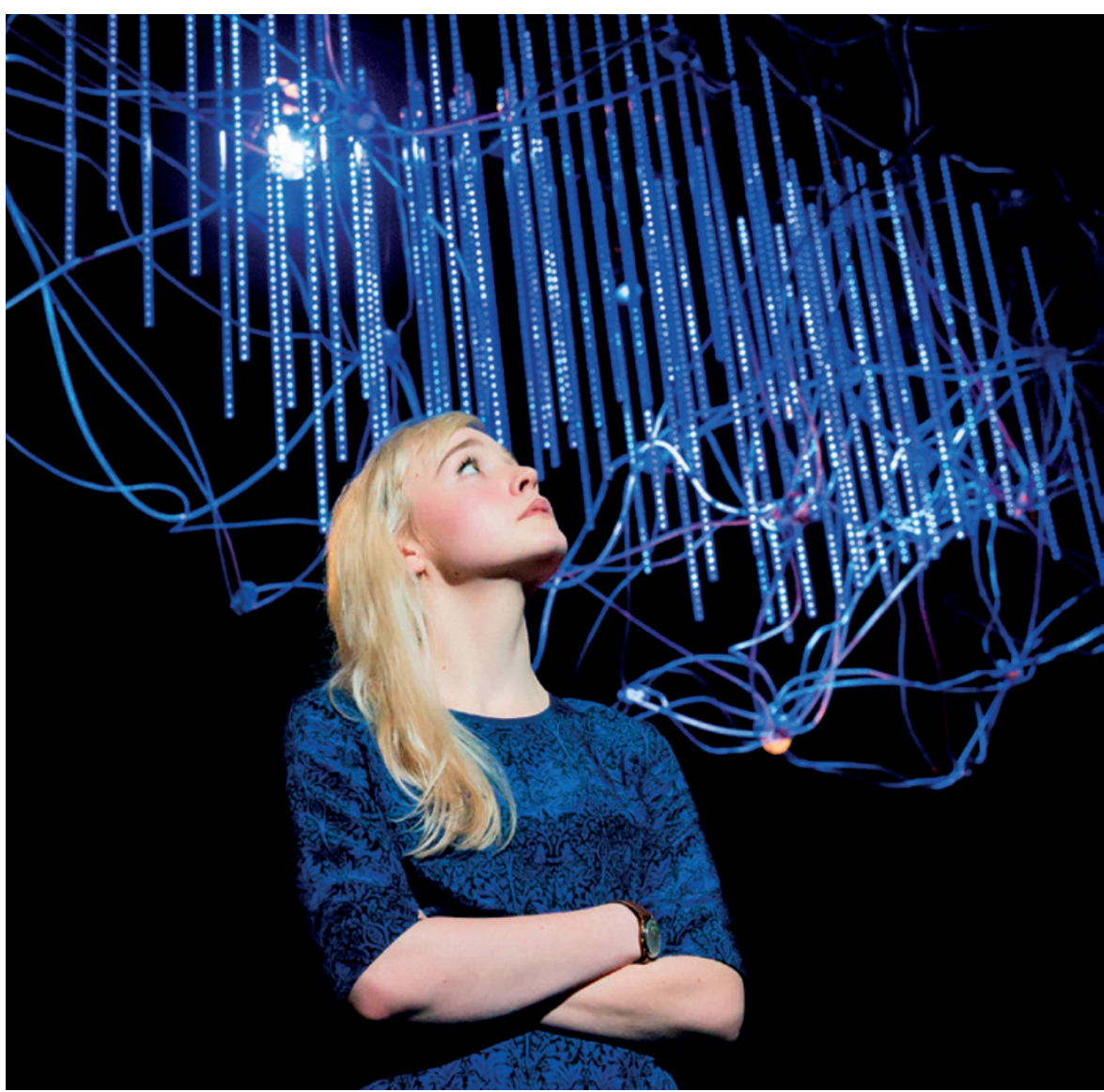

Olivia Vinall plays Hilary, the researcher at the centre of The Hard Problem.

NEUROSCIENCE

\title{
Drama of consciousness
}

\section{Alison Abbott analyses Tom Stoppard's latest play, which tackles the crucial question in neuroscience.}

\section{$\mathrm{T}$} he protagonist of Tom Stoppard's The Hard Problem is an enigma. Although self-doubting, young psychologist Hilary is nevertheless sure of her own unconventional line of scientific inquiry. She is on the road to a successful scientific career, but seems to be caught in a moral trap of her own making that threatens to derail that career.

Stoppard's first new play in nine years is also a bit of an enigma. It takes on human consciousness - self-awareness and the ability to reflect on oneself and the world. The 'hard problem' has vexed philosophers for millennia, and psychologists for centuries. Where does consciousness arise? In the soggy grey mass of the brain, as materialists would have it? Or 'elsewhere' - assigned down the ages variously to God or the cosmos - as dualists argue? In the past few decades, neuroscientists have rendered dualism redundant, although they have yet to work out the details. The play contemplates these issues and draws parallels with the world of finance.

Through the character of Hilary, Stoppard seems to claim that dualism is still relevant, even as he gives his protagonist arguments that are both intellectually and emotionally implausible. The play follows the bumpy path of Hilary's early research career. Much of the turbulence is created by a secret grief: a daughter, born of a teenage pregnancy, given up for adoption. A mediocre student of psychology - with a poor grasp of mathematics and an over-developed sense of ethics - Hilary is lucky to land a $\mathrm{PhD}$ position and then a principal-investigator post at the elite, privately funded Krohl Institute for Brain Science. Here, she is out of her league and out of step with her colleagues, who are hard-core neuroscientists. She wants to prove that
The Hard Problem TOM STOPPARD National Theatre, London. Until 27 May.
Darwinist theories cannot explain goodness and altruism. She survives, perhaps because her mentors and students, male and female, fall in love with her. Then a scientific fraud changes everything.

It is hard not to be thrilled by this fastpaced romp through buzz concepts - such as the idea that the brain is a biological supercomputer. It is also difficult not to be impressed by the references to contemporary experimental methods, including optogenetics, which neuroscientists use to observe neural circuits in action in animals that are awake. (The Krohl institute celebrates getting on the cover of Nature for a discovery in that field.) Stoppard also references many of the ethical debates faced by those who work on the brain or mind, from the use of animals in research to who should take the rap for any scientific fraud.

As if all that were not enough for one 100-minute, one-act play, Stoppard also brings in finance and its parallels with neuroscience, at least in terms of reliance on mathematics. Mathematically gifted hedge-funders with no feel for the reality of financial markets get personally rich while crashing the system with a trickiness that is opaque to outsiders. A mathematically gifted research student with no feel for psychology uses tricks to manipulate data in the hope of impressing Hilary, her boss. Their smaller system crashes. The question lingers: if neuroscience has become dependent on calculations that outsiders cannot understand, can we trust its theories of the brain as a biological computer and seat of the mind?

The play strains under the weight of this load, yet Stoppard's gift for dialogue keeps the action afloat. And there are moments of exquisite poignancy. At one point, Hilary confesses that she needed to invent something like God for herself to provide a structure - prayer - within which she could remember her daughter every day.

The other characters are largely stereotypes. Spike, Hilary's tutor at university and occasional lover, is the cocky, emotionally inept rationalist. Amal is the brilliant mathematician from India, equally happy to ply his skills in neuroscience or in finance. Jerry Krohl is the philanthropic plutocrat hoping for immortality.

The Hard Problem does not build up to a coherent whole. Yet it does science a service by airing the full range of research and ethical questions in psychology and neuroscience for wider general discussion. In my view, science will resolve the hard problem in the next few decades. In the meantime, it is good to see its fundamental importance take centre stage.

Alison Abbott is Nature's senior Europe correspondent. 